results have been of great value to geological surveys throughout the British Empire. He was elected a fellow of the Royal Society in 1950.

Mr. E. S. Calvert, a research engineer at the Royal Aircraft Establishment who has made a special study of visual aids for the landing of aircraft in bad visibility. As a result of his work the whole subject of runway lighting has been completely transformed.

Dr. A. P. Guinand, of the Military College of Science, Shrivenham, who, as the author of many papers on Fourier integrals and their generalizations, and on the application of harmonic analysis in the theory of numbers, is well known for his work in pure mathematics.

Dr. W. C. Hodgson, of the Fisheries Laboratory, Lowestoft, of the Ministry of Agriculture and Fisheries, is responsible for studies on herring biology which have resulted in a series of remarkably success ful forecasts of the great East Anglian herring fishery. Since the War, he has revealed that considerable use can be made of echo-sounding as a means of locating and identifying shoals of pelagic fish.

Mr. R. B. Robertson-Shersby-Harvie, an engineer who has specialized in the design of high-energy electron accelerators. In 1945 he proposed the travelling-wave method of accelerating electrons in a motal corrugated guide. $\mathrm{He}$ has taken a major part in the successful application and development of the method, and has recently proposed an original type of dielectric-loaded wave-guide, which should allow a considerable improvement in accelerator efficiencies.

Mr. A. G. D. Watson, of the Royal Naval Scientific Service, is a mathematician who has considerable accomplishments both as a pure mathematician and as an able experimenter, having had wide laboratory and trials experience. A fellow of King's College, Cambridge, he joined the Admiralty in 1939. His analytical work in circuit theory and in radio propagation has been of outstanding importance to the Royal Navy, and he has made many valuable contributions in this field.

\section{Royal Society's Depository of Unpublished Mathematical Tables}

The Mathematical Tables Committee of the Royal Society believes that there are in the possession of British computers and other persons tables of mathematical functions which, because of their length, their limited interest, or some other reason, have not been published. Nevertheless, these tables may sometimes be of considerable value to other workers, and accordingly the Committee is prepared to consider accepting them for deposition in the library of the Royal Society. Lists will be published periodically of the tables which have been accepted. The tables will be available for examination in the library, and it is proposed to arrange for photo-copies to be supplied at a reasonable charge to those who desire them. It is hoped to build up in this way a collection of tables which would otherwise be less generally accessible, and which, in the course of time, should become very valuable. Communications should be sent to the assistant secretary of the Royal Society, Burlington House, Piccadilly, London, W.l.

\section{Early History of Science}

To meet the needs of those students of the early history of science who cannot easily consult bibliographies and reviews, the Historical Association has published a short handlist. The list contains details of periodicals, bibliographies and general histories of science and of particular sciences, as well as sections dealing with the pre-classical, classical, Islamic, medieval Christian, Renaissance (1500-1650) and. early modern (1650-1800) periods. In each of these sections reference is made to general works as well as publications in astronomy and astrology, botany, geography, mathematics, mechanies, medicine, the physical sciences and technology. The handlist indicates works of interpretation rather than editions of original texts, while books in English have been mentioned rather than those in foreign languages. Since it is not likely to supply an urgent need in the case of students in Great Britain, no section on works on the Far East and India has been included. All students of the early history of science will welcome the appearance of this handlist, although a surprising omission from the general histories is H. D. Anthony's "Science and its Background", while H. A. Reason's "Road to Modern Science" and F. Houk Law's "Civilisation Builders" might also have been included. The handlist may be obtained from the Historical Association, 21 Bedford Square, London, W.C.1, price 2s. $6 d$.

\section{Earthquakes during April-July}

DURING the four months April-July 1950, some 98 large earthquakes, 188 minor ones and a multitude of earth tremors were recorded. Many of the large earthquakes were notable because of their great magnitude or great depth of focus or the material damage which they did. The earthquake of greatest magnitude which occurred during the period was on May 26 with epicentre in the New Hebrides. This reached magnitude $7 \frac{1}{2}$ on the instrumental scale. The shock of May 25, which took place 150 miles west of Guam, attained a magnitude of $7 \frac{1}{4}$ on the same scale, and six earthquakes reached magnitude 7 . These latter took place on May 17 off the east coast of Korea; on May 17 in the New Hebrides region; on July 9 (two shocks) in western Brazil ; on July 13 in the Bonin Islands region; and on July 29 in the Solomon Islands region. Five earthquakes came from foci $600 \mathrm{~km}$. deep, some of these already having been mentioned above. These five occurred on May 17 off the east coast of Korea; on May 27 in the Fiji Islands; on May 30 in the Tonga Islands ; on July 9 in western Brazil ; and on July 10 again in the Fiji Islands region. The deepest earthquakes ever recorded appear to come from a depth only slightly greater than $700 \mathrm{~km}$.

On Sunday, May 22, the city of Cuzco in Peru, which was once the capital of the Incas and which stands at a height of $11,400 \mathrm{ft}$. in the Andes, was shaken by an earthquake which destroyed some twenty per cent of the buildings there. There were many worshippers in the churches when some of the latter were seriously damaged. More than a hundred people in all are reported killed and some two hundred injured as a result of the earthquake. Five earthquakes between 9.30 p.m. on July 8 and 5.30 p.m. on the following day shook north and central Colombia, doing considerable damage and causing many casualties. The epicentres were near the towns of Arboleda and Cucutilla. Salazar de Las Palmas was also damaged, together with other towns and villages in the neighbourhood. Total casualties are reported to number two hundred dead and five hundred injured. During the four months, strong earthquake shocks and tremors in the Old World have been reported from twenty-seven localities, including Livorno on April 1; Jersey on April 13; the Gulf of Aden on 